\title{
The fluorine link between a supergiant ore deposit and a silicic large igneous province
}

\author{
Jocelyn McPhie ${ }^{1}$, Vadim Kamenetsky ${ }^{1}$, Sharon Allen ${ }^{1}$, Kathy Ehrig ${ }^{2}$, Andrea Agangi ${ }^{1}$, and
} Adam Bath ${ }^{1}$

${ }^{1}$ ARC Centre of Excellence in Ore Deposits and School of Earth Sciences, University of Tasmania, Hobart, Tasmania 7001, Australia

2BHP Billiton, 55 Grenfell Street, Adelaide, South Australia 5000, Australia

\section{ABSTRACT}

Olympic Dam is a supergiant Fe oxide Cu-U-Au-Ag ore deposit $\left(\sim 9 \times 10^{9}\right.$ t) that is also enriched in rare earth elements (REEs) and fluorine $(F)$. The immediate host to the ore is hydrothermal breccia within granite and volcanic rocks of a Mesoproterozoic silicic large igneous province. Analyses of melt inclusions in quartz phenocrysts in rhyolite show that the silicic magmas of this province were unusually rich in $\mathrm{F}$ (up to $1.3 \mathrm{wt} \%$ ). Fluorite and other F-rich minerals that crystallized from these magmas provided a gigantic reservoir of F. As a result, the Olympic Dam ore-forming fluid was F-rich and had exceptional capacity to transport diverse elements. Further, we infer that hydrofluoric acid, the most corrosive acid known, contributed to hydrothermal breccia formation by dissolution that in turn increased permeability and accelerated the rate of fluid-rock interaction. It is no accident that the world's largest hydrothermal ore deposit occurs in an F-rich silicic large igneous province.

\section{INTRODUCTION}

The metal enrichment that characterizes hydrothermal ore deposits is generally attributed to precipitation of metal-rich minerals from hot, metal-bearing aqueous fluids (Seward and Barnes, 1997). In many cases, questions relating to the fluid source, fluid composition, and the metal potential of the fluid remain unanswered. These questions are especially challenging for supergiant ore deposits, those in which the ore body exceeds $24 \times 10^{6} \mathrm{t}$ of $\mathrm{Cu}$ or $1200 \mathrm{t}$ of Au (Singer, 1995). Sources of both the fluids and the metals must be consistent with the setting, style, age, and size of the ore deposit. Because most metal solubilities in aqueous fluids are very low $\left(<10^{-4} \mathrm{ppm}\right)$, unrealistically high fluid volumes and flow rates are inferred (Krauskopf, 1967). However, the capacity of aque- ous fluids to transport and concentrate metals is greatly enhanced if $\mathrm{OH}^{-}, \mathrm{Cl}^{-}$, and $\mathrm{HS}^{-}$are present because these ligands readily combine with met- als to form aqueous complexes and thereby increase solubilities (Seward and Barnes, 1997; Wood and Samson, 1998). Fluorine is also a powerful ligand for metal transport (Seward and Barnes, 1997; Wood and Samson, 1998), being the most reactive and electronegative of all elements, but there are few settings where $F$ is abundant and 
available to hydrothermal fluids (Aiuppa et al., 2009; Pyle and Mather, 2009).

The Olympic Dam ore deposit is famous for its supergiant size and spectacular array of elements present at concentrations $\left(0.87 \mathrm{wt} \% \mathrm{Cu}, 0.27 \mathrm{~kg} / \mathrm{t} \mathrm{U} \mathrm{U}_{8}, 0.32 \mathrm{~g} / \mathrm{t} \mathrm{Au}, 1.50 \mathrm{~g} / \mathrm{t} \mathrm{Ag}\right)(\mathrm{BHP}$ Billiton, 2010) well above the crustal average (Cu 158 times, U 92 times, Au 80 times, Ag 300 times) (cf. Wedepohl, 1995). It contains in excess of $70 \times 10^{6} \mathrm{t}$ of $\mathrm{Cu}$ alone. In addition, the combined La and Ce concentration in the ore is $\sim 5000$ ppm, so these REEs are hundreds of times more abundant than in average crust (a few tens of ppm; Wedepohl, 1995). The immediate host to the ore is hydrothermal breccia within granitic and volcanic rocks of a Mesoproterozoic silicic large igneous province (SLIP) (Fig. 1) (Fan- ning et al., 1988; Reeve et al., 1990; Johnson and Cross, 1995; Allen et al., 2008). The connection between this SLIP and Olympic Dam has not been adequately considered in studies of ore genesis (e.g., Reeve et al., 1990; Oreskes and Einaudi, 1990; Johnson and Cross, 1995; Haynes et al., 1995). Here we show that this igneous province was unusually rich in $F$, using data from melt inclusions in quartz phenocrysts in rhyolite. We also show that much of the original $F$ was fixed in rhyolite and granite by means of widespread crystallization of fluorite and other F-rich minerals. We argue that this F-rich setting was crucial because any fluid involved in the Olympic Dam oreforming hydrothermal system would have been F-rich and capable of transporting metals and REEs on the scale required to create this supergiant.

\section{OLYMPIC DAM Cu-U-Au-Ag DEPOSIT}

The Olympic Dam ore deposit is hosted by hematite-rich breccias that are totally contained within the Roxby Downs Granite, a coarse-grained, equigranular granite mainly composed of alkali feldspar, plagioclase, and quartz, and minor amphibole and biotite (Reeve et al., 1990). The princi- pal ore minerals are Cu sulfides and U oxides (Roberts and Hudson, 1983; Reeve et al., 1990) that occur as disseminated grains in the breccia. Most of the clasts in the hematite-rich breccia are granite, derived from the Roxby Downs Granite, but volcanic clasts are locally abundant. The hematite-rich breccia is immediately surrounded by a 1-2 km wide zone of brecciated Roxby Downs Granite. The brecciation at Olympic Dam was probably ini- tiated and focused on multiple faults, but is largely hydrothermal in origin (Reeve et al., 1990; Oreskes and Einaudi, 1990) and has affected a volume of rock on the order of 5 $\mathrm{km}^{3}$, making the Olympic Dam breccia complex one of the largest known hydrothermal breccia bodies (cf. Sillitoe, 1985).

\section{Fluorine at Olympic Dam}

Olympic Dam is enriched in F (Roberts and Hudson, 1983; Reeve et al., 1990; Oreskes and Einaudi, 1990; Haynes et al., 1995), and there is an intimate association between Cu sulfides and fluorite in the hematite-rich breccias. Fluorite is common, being present as disseminated crystals, crystal fragments, and in veins. Some $2.5 \mathrm{wt} \%$ of the ore mined consists of fluorite which means that the $\mathrm{F}$ 
content due to fluorite alone is $\sim 10^{8} \mathrm{t}$ (22 times the crustal average of 550 ppm; Wedepohl, 1995; Pyle and Mather, 2009). In addition, the principal alteration minerals have high F content (chlorite $\sim 0.4 \mathrm{wt} \%$, sericite $\sim 0.8$ wt\%, apatite $\sim 5.3$ wt\%; Table DR1 in the GSA Data Repository ${ }^{1}$ ). On a deposit scale, the hematite-rich breccias that contain high amounts of fluorite also have the highest abundance of $\mathrm{Cu}$ sulfides (Reeve et al., 1990), and Cu sulfide and fluorite typically occur together (Fig. 2A) (Oreskes and Einaudi, 1990). The main REE-bearing minerals in the ore are bastnäsite, synchysite, and florencite, all of which contain $\mathrm{F}$, and fluid inclusion analyses suggest the presence of $\mathrm{F}$ in the hydrothermal fluid (Oreskes and Einaudi, 1990, 1992).

\section{GAWLER SILICIC LARGE IGNEOUS PROVINCE}

The pluton that hosts Olympic Dam is part of the undeformed, unmetamorphosed Mesoproterozoic Gawler SLIP, comprising granitoid intrusions (Hiltaba Suite) and subaerial volcanic rocks (Gawler Range Volcanics) (Flint, 1993; Allen et al., 2008) (Fig. 1). In the Olympic Dam area, the Gawler SLIP units are unconformably covered by younger sedi- mentary formations, but they are well exposed $200 \mathrm{~km}$ to the southwest. About two-thirds of the Gawler SLIP is volcanic, and the volcanic units are predominantly silicic (90\% rhyolite and dacite; Allen et al., 2008). The succession is remarkable for the volume of rhyolitic and dacitic lavas produced throughout its history. More than ten lavas have volumes in the range $10-50 \mathrm{~km}^{3}$, and at least three lavas have volumes in excess of 500 km3 (Garner and McPhie, 1999; Allen and McPhie, 2002; Allen et al., 2003, 2008). Radiometric ages for the preserved volcanic units suggest that volcanism lasted only 1-2 m.y. at ca. $1592 \mathrm{Ma}$ (Fanning et al., 1988). The granitoid intrusions of the Hiltaba Suite are also predominantly silicic (granite, quartz monzonite); their ages (ca. 1598-1583 Ma) (Creaser and Cooper, 1993; Flint, 1993) span a longer interval than the volcanic rocks.

\section{Fluorine Content of the Gawler SLIP Magmas}

We have discovered that the Gawler SLIP magmas were especially F-rich. Melt inclusions in quartz phenocrysts in rhyolites in the Gawler Range Volcanics have major and trace element compositions representa- tive of volcanic and intrusive rocks in the province (Fig. 3). Thus, the $F$ content measured in melt inclusions records magmatic $\mathrm{F}$ abundance and ranges up to $1.3 \mathrm{wt} \%$ (Fig. 3B; Table DR2), far in excess of the aver- age abundance of $F$ in the upper crust ( 0.05 wt\%; Wedepohl, 1995; Pyle and Mather, 2009). The large magma volume estimated for the Gawler SLIP ( 90,000 km³; McPhie et al., 2008) implies that the F initially pres- ent amounted to some $10^{12} \mathrm{t}$. The $\mathrm{F}$ content of the silicic magmas was so high that fluorite crystallized in the melt inclusions as a daughter phase (Fig. 2B), and is present as inclusions in quartz phenocrysts (Fig. 2C). F-bearing magmatic minerals (e.g., topaz, bastnäsite, biotite $~ 3.7 \mathrm{wt} \% \mathrm{~F}$, amphibole $2.0 \mathrm{wt} \% \mathrm{~F}$, sphene $\sim 2 \mathrm{wt} \%$ $\mathrm{F}$; Table DR1), and more impor- tantly, magmatic fluorite in volcanic rocks and intrusions (Figs. $2 \mathrm{C}$ and 2D), indicate that the magmas were saturated in $\mathrm{F}$ at the time of crystal- lization. The presence of 
fluorite in vesicles and micromiarolitic cavities in the rhyolitic lavas, and in miarolitic cavities and interstitial sites in gran- ites, implies that some $\mathrm{F}$ was exsolved into a late magmatic-hydrothermal fluid phase (Agangi et al., 2010). We infer that the high $\mathrm{F}$ concentrations were responsible for the largevolume silicic volcanic units in the Gawler SLIP being lavas rather than ignimbrites because $F$ has the effect of lower- ing melt viscosity (Giordano et al., 2004), which in turn favors an effusive (rather than explosive) eruption style.

\section{DISCUSSION}

The high abundance of fluorite at Olympic Dam has long been recog- nized (Roberts and Hudson, 1983). However, the source of $F$ has hitherto been unresolved. We propose that the $F$ in Olympic Dam ore ultimately originated from the Gawler SLIP magmas. The enrichment of $U$ and REEs in Olympic Dam reinforces its connection with the Gawler SLIP. Olympic Dam is the premier deposit in the "Olympic Cu-Au-(U) province" (Skir- row et al., 2007), in which all deposits and prospects are associated with the Gawler SLIP. Many of the deposits are known to be enriched in F and all are REErich (Skirrow et al., 2007).

There is a further point of significance to the elevated $\mathrm{F}$ in the Olympic Dam hydrothermal system. The hydrothermal breccia that hosts Olympic Dam contains abundant angular and splinter-shaped clasts that are readily explained by conventional hydrothermal fragmentation processes such as brittle fracture in response to fluid overpressure (Sillitoe, 1985). However, there is also a large population of clasts with distinctive irregular and amoe- boid shapes (Fig. 4). These shapes are exhibited by hydrothermally altered clasts of both volcanic rock types (Fig. 4A) and granite (Fig. 4B). Such shapes are best accounted for by dissolution of volcanic and granitic wall rock. Given the F-rich character of the Olympic Dam hydrothermal sys- tem, we infer that hydrofluoric acid (HF) was responsible. This acid is one of the most corrosive known and is used routinely to dissolve silicate rocks in geochemical analyses. All igneous wall rocks (the Roxby Downs Gran- ite pluton, the local GRV lavas) were already solid when the breccia com- plex formed, and incapable of directly outgassing F. Alternatively, there are a number of pathways for the $\mathrm{F}$ in fluorite and other magmatic minerals to enter meteoric or hydrothermal fluids as HF. For example, HF could have been created by reactions between fluorite-rich volcanic, sedimentary, and granitic rocks and acidic groundwater formed in and around pyritic fault zones. Once focused on a fracture or fault, wall-rock dissolution by HF would have increased permeability and porosity that in turn enhanced and focused hydrothermal fluid flow. The unusually large volume of hydrother-mal breccia at Olympic Dam may be explained by HF corrosion acting in concert with other hydrothermal fragmentation mechanisms.

\section{CONCLUSIONS}

We conclude that the supergiant Olympic Dam ore deposit is a predictable product of its setting within an F-rich SLIP. The preponderance of large-volume silicic lavas in this province is another 
consequence of the high- $F$ character of the silicic magmas. The huge amount of $F$ contained by this SLIP meant the Olympic Dam hydrothermal system, and others in the region, had to be F-rich.

Fluorine-rich hydrothermal fluids were substantially responsible for the high metal content (including REEs) of the Olympic Dam ore deposit and its polymetallic character, and contributed to the formation of the hydrothermal breccia that hosts the ore. The Olympic Dam case demonstrates that while LIP magmas in general are implicated as fluid and metal sources for supergiant ore deposits, simply because of the huge volumes of magma from which fluids and metals can be derived, F-rich SLIPs have superior ore potential.

\section{ACKNOWLEDGMENTS}

This project was funded by the Australian Research Council and BHP Bil- liton. Fieldwork was supported by Primary Industries and Energy, South Australia. Discussions with R. Large, S. Meffre, R. Maas, I. Chambefort, and K. Cross are gratefully acknowledged. Analyses were obtained with the help of Karsten Goe- mann. We thank Jake Lowenstern, an anonymous referee, and Bill Collins for help- ful comments.

\section{REFERENCES CITED}

Agangi, A., Kamenetsky, V.S., and McPhie, J., 2010, The role of fluorine in the concentration and transport of lithophile trace elements in felsic magmas: Insights from the Gawler Range Volcanics, South Australia: Chemical Ge- ology, v. 273, p. 314-325, doi: 10.1016/j.chemgeo.2010.03.008.

Aiuppa, A., Baker, D.R., and Webster, J.D., 2009, Halogens in volcanic systems: Chemical Geology, v. 263, p. 1-18, doi: 10.1016/j.chemgeo.2008.10.005.

Allen, S.R., and McPhie, J., 2002, The Eucarro Rhyolite, Gawler Range Volca- nics, South Australia: A >675 km³, compositionally zoned lava of Mesopro- terozoic age: Geological Society of America Bulletin, v. 114, p. 1592-1609, doi: 10.1130/0016-7606(2002)114<1592:TERGRV>2.0.CO;2.

Allen, S.R., Simpson, C.J., McPhie, J., and Daly, S.J., 2003, Stratigraphy, distri- bution and geochemistry of widespread felsic volcanic units in the Meso- proterozoic Gawler Range Volcanics, South Australia: Australian Journal of Earth Sciences, v. 50, p. 97-112, doi: 10.1046/j.14400952.2003.00980.x.

Allen, S.R., McPhie, J., Ferris, G., and Simpson, C., 2008, Evolution and archi- tecture of a large felsic igneous province in western Laurentia: The 1.6 Ga Gawler Range Volcanics, South Australia: Journal of Volcanology and Geothermal Research, v. 172, p. 132-147, doi: 10.1016/j.jvolgeores.2005.09.027.

BHP Billiton, 2010, Annual Report, 2010: http://www.bhpbilliton.com/ bbContentRepository/docs/bhpBillitonAnnualReport2010.pdf (May 2011). Creaser, R.A., and Cooper, 
J.A., 1993, U-Pb geochronology of middle Proterozoic felsic magmatism surrounding the Olympic Dam Cu-Au-U-Ag and Moonta Cu-Au-Ag deposits, South Australia: Economic Geology and the Bulletin of the Society of Economic Geologists, v. 88, p. 186-197, doi: 10.2113/ gsecongeo.88.1.186.

Fanning, C.M., Blissett, R.B., Parker, A.J., Ludwig, K.R., and Blissett, A.H., 1988, Refined Proterozoic evolution of the Gawler Craton, South Australia, through U-Pb geochronology: Precambrian Research, v. 40-41, p. 363-386, doi: 10.1016/0301-9268(88)90076-9.

Flint, R.B., 1993, Mesoproterozoic, in Drexel, J.F., et al., eds., The geology of South Australia, volume 1: The Precambrian: Geological Survey of South Australia Bulletin 54, p. 107-169.

Garner, A., and McPhie, J., 1999, Partially melted lithic megablocks in the Yardea Dacite, Gawler Range Volcanics, Australia: Implications for eruption and emplacement mechanisms: Bulletin of Volcanology, v. 61, p. 396-410, doi:10.1007/s004450050281.

Giordano, D., Romano, C., Dingwell, D.B., Poe, D., and Behrens, H., 2004, The combined effects of water and fluorine on the viscosity of silicic magmas: Geochimica et Cosmochimica Acta, v. 68, p. 5159-5168, doi: 10.1016/j.gca.2004.08.012.

Haynes, D.W., Cross, K.C., Bills, R.T., and Reed, M.H., 1995, Olympic Dam ore genesis: A fluid-mixing model: Economic Geology and the Bulletin of the Society of Economic Geologists, v. 90, p. 281-307, doi: 10.2113/ gsecongeo.90.2.281.

Johnson, J.P., and Cross, K.C., 1995, U-Pb geochronological constraints on the genesis of the Olympic Dam Cu-U-Au-Ag deposit, South Australia: Eco- nomic Geology and the Bulletin of the Society of Economic Geologists, v. 90, p. 1046-1063, doi: 10.2113/gsecongeo.90.5.1046.

Krauskopf, K.B., 1967, Introduction to geochemistry: New York, McGraw-Hill, McDonough, W.F., and Sun, S.-S., 1995, The composition of the Earth: Chemical Geology, v. 120, p. 223-253, doi: 10.1016/0009-2541(94)00140-4.

McPhie, J., Della-Pasqua, F., Allen, S.R., and Lackie, M.A., 2008, Extreme effu- sive eruptions: Palaeoflow data on an extensive felsic lava in the Mesopro- terozoic Gawler Range Volcanics: Journal of Volcanology and Geothermal Research, v. 172, p. 148-161, doi: 10.1016/j.jvolgeores.2006.11.011.

Oreskes, N., and Einaudi, M.T., 1990, Origin of rare earth element-enriched he- matite breccias at the Olympic Dam Cu-U-Au-Ag deposit, Roxby Downs, South Australia: Economic Geology and the Bulletin of the Society of Eco- nomic Geologists, v. 85, p. 1-28, doi: 10.2113/gsecongeo.85.1.1.

Oreskes, N., and Einaudi, M.T., 1992, Origin of hydrothermal fluids at Olympic Dam: Preliminary results from fluid inclusions and stable isotopes: Eco- nomic Geology and the Bulletin 
of the Society of Economic Geologists, v. 87, p. 64-90, doi: 10.2113/gsecongeo.87.1.64.

Pyle, D.M., and Mather, T.A., 2009, Halogens in igneous processes and their fluxes to the atmosphere and oceans from volcanic activity: A review: Chemical Geology, v. 263, p. 110-121, doi: 10.1016/j.chemgeo.2008.11.013.

Reeve, J.S., Cross, K.C., Smith, R.N., and Oreskes, N., 1990, Olympic Dam copper-uraniumgold-silver deposit, in Hughes, F.E., ed., Geology of the mineral deposits of Australia and Papua New Guinea: Melbourne, Austra- lian Institute of Mining and Metallurgy, p. 1009-1035.

Roberts, D.E., and Hudson, G.R.T., 1983, The Olympic Dam copper-uranium- gold deposit, Roxby Downs, South Australia: Economic Geology and the Bulletin of the Society of Economic Geologists, v. 78, p. 799-822, doi: 10.2113/gsecongeo.78.5.799.

Seward, T.M., and Barnes, H.L., 1997, Metal transport by hydrothermal ore flu- ids, in Barnes, H.L., ed., Geochemistry of hydrothermal ore deposits: New York, John Wiley and Sons, p. 435-486.

Sillitoe, R.H., 1985, Ore-related breccias in volcanoplutonic arcs: Economic Geology and the Bulletin of the Society of Economic Geologists, v. 80, p. 1467-1514, doi:

10.2113/gsecongeo.80.6.1467.

Singer, D.A., 1995, World class base and precious metal deposits: A quantitative analysis: Economic Geology and the Bulletin of the Society of Economic Geologists, v. 90, p. 88-104, doi: 10.2113/gsecongeo.90.1.88.

Skirrow, R.G., Bastrakov, E.N., Barovich, K., Fraser, G.L., Creaser, R.A., Fan- ning, C.M., Raymond, O.L., and Davidson, G.J., 2007, Timing of iron ox- ide Cu-Au-(U) hydrothermal activity and $\mathrm{Nd}$ isotope constraints on metal sources in the Gawler Craton, South Australia: Economic Geology and the Bulletin of the Society of Economic Geologists, v. 102, p. 1441-1470, doi:10.2113/gsecongeo.102.8.1441.

Wedepohl, K.H., 1995, The composition of the continental crust: Geochimica et Cosmochimica Acta, v. 59, p. 1217-1232, doi: 10.1016/0016-7037(95)00038-2.

Wood, S.A., and Samson, I.M., 1998, Solubility of ore minerals and complex- ation of ore metals in hydrothermal solutions: Reviews in Economic Geol- ogy, v. 10, p. 33-77.

\section{Figure captions}

Figure 1. Simplified geological map of South Australia. SLIP—silicic large igneous province; GRV—Gawler Range Volcanics. Modified after Skirrow et al. (2007). 
Figure 2. Fluorite occurrences at Olympic Dam and in the Gawler silicic large igneous province (SLIP). A: Intergrown fluorite and chal- cocite (opaque) crystals. Sample RD3449, $431.4 \mathrm{~m}$, scale bar $100 \mu \mathrm{m}$. B: Fluorite daughter crystals in a melt inclusion hosted by a quartz phenocryst in the Gawler SLIP rhyolite. Sample GC8, scale bar $50 \mu \mathrm{m}$. C: Fluorite crystal in a quartz phenocryst in Gawler SLIP rhyo- lite. Sample GC15, scale bar $20 \mu \mathrm{m}$. D: Interstitial fluorite crystal in the Hiltaba Suite granite. Sample HS1, scale bar $500 \mu \mathrm{m}$.

Figure 3. Compositions of heated and unheated melt inclusions, groundmass, and whole-rock samples in the Gawler silicic large igneous province (SLIP). A: Average trace elements normalized to primitive mantle (McDonough and Sun, 1995). B: F versus SiO2 (wt\%). GRV—Gawler Range Volcanics.

Figure 4. Amoeboid clasts in Olympic Dam hematite-rich breccias. A: Volcanic clast. Drill core RD2749, $551.2 \mathrm{~m}$, scale bar $2 \mathrm{~cm}$. B: Gra- nitic clast. Drill core RD2749, $614.0 \mathrm{~m}$, scale bar $1 \mathrm{~cm}$. 


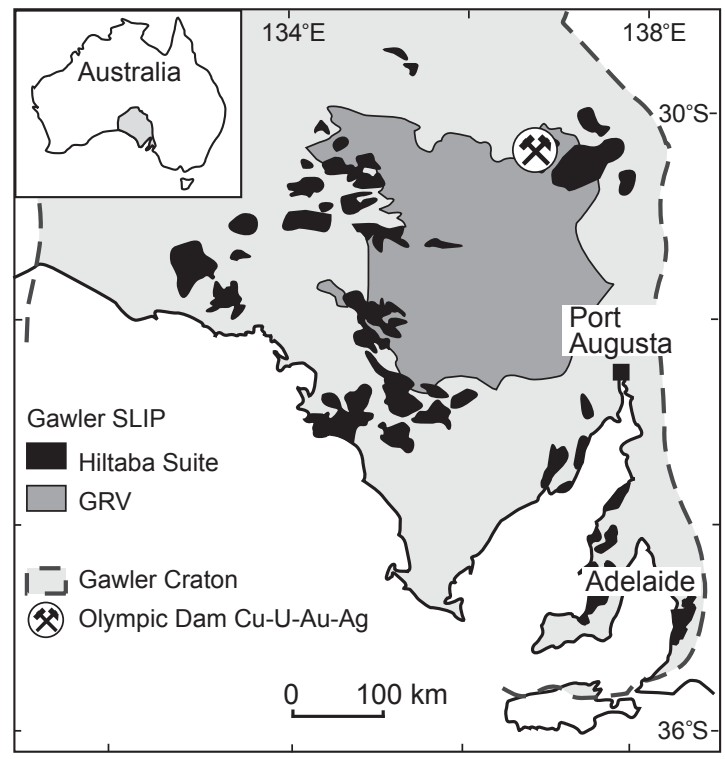

Figure 1 


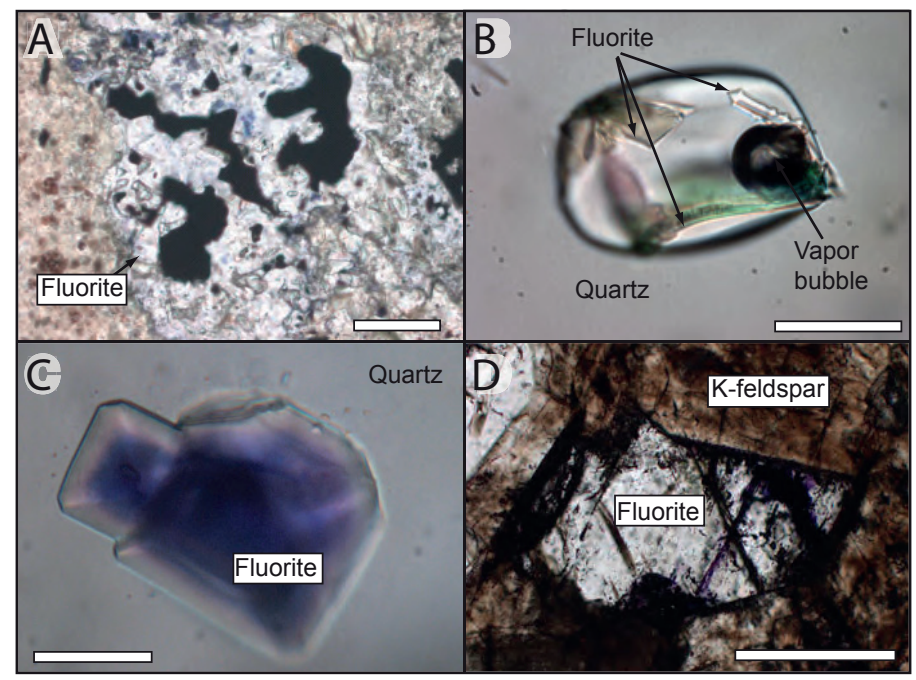

Figure 2. 

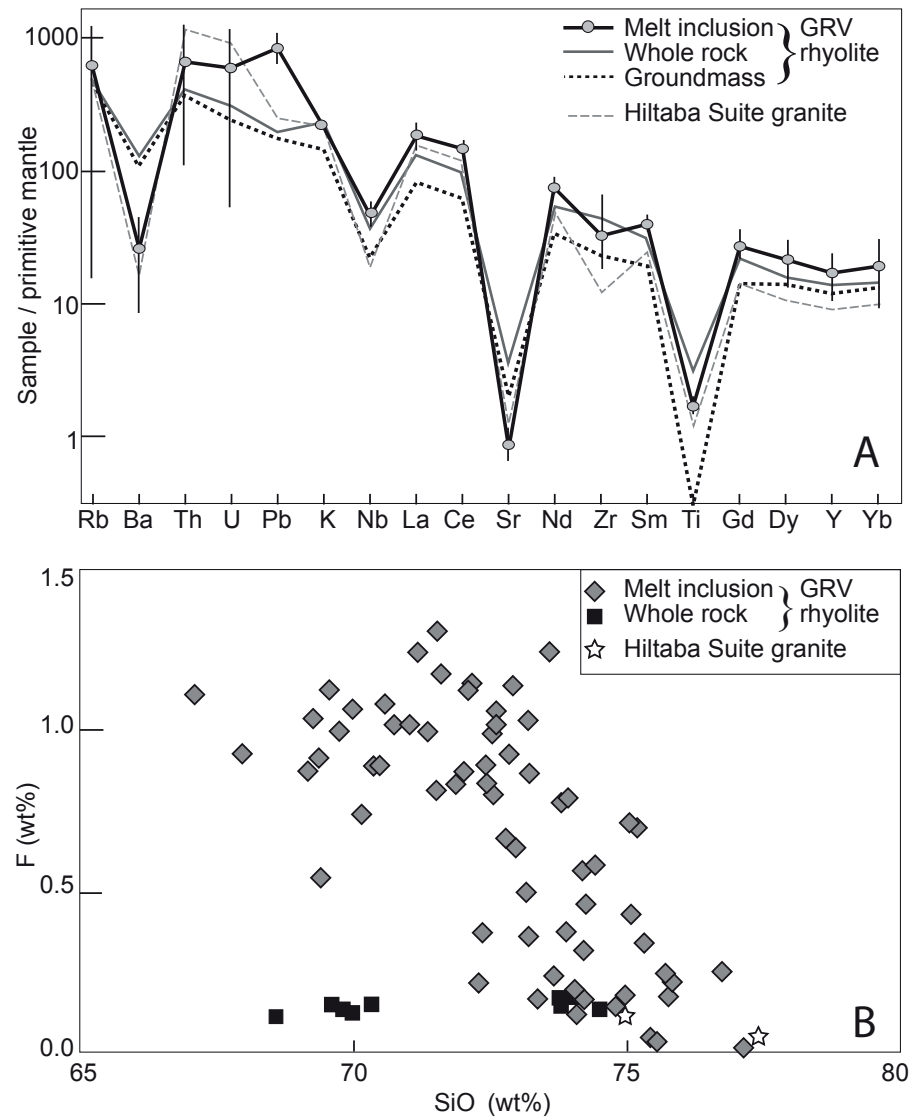

Figure 3 


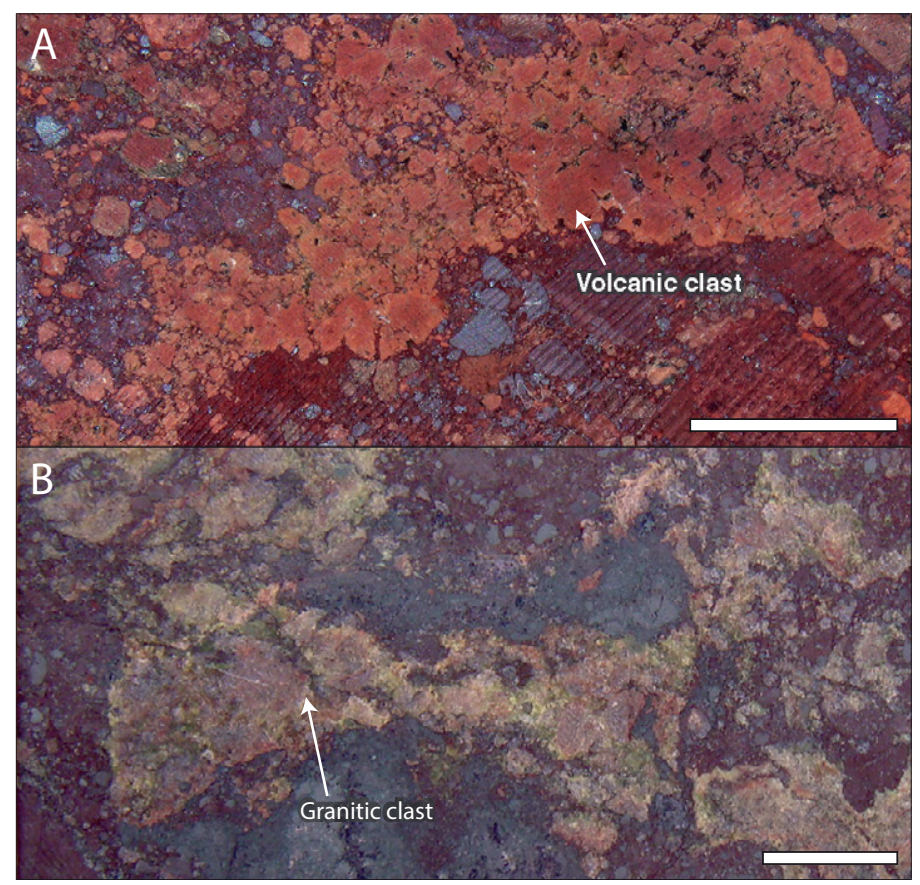

Figure 4 